Przegląd Badań Edukacyjnych Educational Studies Review

ISSN 1895-4308

nr $30(1 / 2020)$, s. 45-64
ORYGINALNE ARTYKUtY BADAWCZE

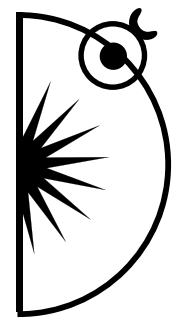

Aleksandra Jasińska-Maciążek

ORCID: http://orcid.org/0000-0001-9975-4141

University of Warsaw, Poland; e-mail: a.jasinska@uw.edu.pl

\title{
Does the Use of Electronic Gradebooks Affect Schooling Outcomes? A Study in Polish Primary Schools
}

http://dx.doi.org/10.12775/PBE.2020.003

\begin{abstract}
The purpose of this study was to determine whether, in the context of Polish primary schools, the use of electronic gradebook raises teaching effectiveness and has altogether any observable educational effects when compared to older, paper forms of record keeping. Our analyses use data from a survey conducted in $2010-2015$ on a nationwide representative sample of 4,500 students from 171 primary schools. Because the electronic gradebook was not yet widely used in Poland at that time, data from this period can be used to analyze the problem stated in the title. The key tools used in our research were standardized school achievement tests and scales examining a student's emotional integration with the school, quality of peer relations and academic self-concept. Measurements were taken after the completion of grades 3 and 6 . The results of intelligence tests and indicators of the economic and social status of the student's family were considered as control variables. Statistical analyses were performed using hierarchical linear regression models. No significant correlation was revealed between the form of the school gradebook and teaching effectiveness in reading, writing or math. Only one of the educational effects included in the study was significantly related to the form of the school gradebook: the use of an electronic form correlated negatively with the level of students' academic self-concept. These results show that the consequences of introducing this type of e-record into schools are more complex than previously considered.
\end{abstract}

Keywords: electronic gradebook, school records, school register, educational outcomes, academic self-concept. 


\section{The e-gradebook in Polish school practice and debate}

The electronic gradebook (e-gradebook) is a software which allows teachers to keep digital records of the course of teaching, assignments, students' progress and grades. In 2009, the Ministry of National Education authorized the use of e-gradebooks at school to replace the paper version ( $\S 1$, section 13 of the MEN Regulation of 16 July 2009), giving schools a choice between the traditional pen-and-paper method, moving to an exclusively electronic system, or mixing the two. The functionality of many e-gradebooks used in Poland goes well beyond reporting (Tuczyński, 2015; Żebrok \& Smyrnova-Trybulska, 2015; Majewska, 2016).

Software suppliers market these tools for their positive educational and care-providing effects (Kempka, 2014). The school heads are also mostly enthusiastic (Stasik, 2015). Many emphasize that e-gradebooks support schoolparent cooperation and make it easier to supervise teachers' work related to record-keeping and grading (Dżus, 2010; Bryska, 2014; Vulcan, n.d.).

The academic articles devoted to e-gradebooks in Polish schools conclude that the tool supports teachers and parents in the educational process, contributing to the reduction of undesirable behaviours, such as truancy or failure to prepare for lessons. They also contribute to higher levels of school achievement due to the immediate provision of information about a child to the parents (e.g. via SMS messages sent by the system). However, these conclusions are either based on the opinions of teachers and parents (Tomaszewska, 2014; Tuczyński, 2015; Żebrok \& Smyrnova-Trybulska, 2015; Majewska, 2016; Zielińska, 2017), or make no reference to empirical data (Wróbel, 2009). To date, no research has been published in Poland attempting to understand the relevance of e-gradebooks to school achievement on the basis of data other than user statements.

Many students are less enthusiastic - a quarter of those who took part in a survey conducted in one of the regions of Poland declared that the e-gradebook made their life difficult (Tomaszewska, 2014). Some complained that their parents had continuous access to information about their grades, others pointed out that it contributed to the deterioration of their relations with parents. Some young people have a sense of loss with regard to having to give up control over their own learning process (Kałużna, 2014). Parents can also see this as a problem (Isio-Kurpińska, 2017), admitting that they find it hard to refrain from the excessive parental control encouraged by continuous access to an e-gradebook. 


\section{Theoretical framework}

The literature on the subject does not offer any straightforward theoretical model of the electronic gradebook and its role in the educational process. Still, it might be helpful to reach into the more general theory of educational effectiveness to organize our thoughts. Most of the opinions about e-gradebooks stem from the belief that they increase school effectiveness, understood as the efficacy of actions taken by the school staff to achieve the desired educational outcomes. In this article, the dynamic model of educational effectiveness is used as a theoretical basis, as it is one of the most important models in the research on school effectiveness (Scheerens, 2013). It assumes that the factors of teaching performance come from four levels: student, class, school and system (Creemers \& Kyriakidēs, 2008). An example of the school-level factor can be a school's policy on informing parents and students about learning results (Creemers \& Kyriakidēs, 2008, p. 83). The system level concerns the relevance of educational policy and the context in which students and school staff function and work (e.g. legal regulations allowing schools to give up paper-based gradebooks in favor of electronic documentation). The dynamic model also organizes the factors of school effectiveness at each level as confirmed by research, which is why it may be very helpful in investigating the mechanisms that may explain a possible relationship between the form of school gradebook and school effectiveness. The factors that can be linked to the way the school records are kept are discussed in more detail below. They are also shown in Figure 1.

At the school level, the model focuses, among other things, on the quantity and quality of teaching (Panayiotou at al., 2016). The use of electronic gradebooks may indeed increase the quantity of teaching. Firstly, thanks to their capacity to immediately inform parents about the absence of their children from school, they reduce the frequency of truancy, as declared by the users of these tools (Majewska, 2016). Secondly, if teachers enter information about homework assignments into the e-gradebook, it may increase the amount of time devoted to homework under parental control and reduce the amount of missing and delayed homework (McGhee, 2000). Thirdly, these tools make it easier to create plans for the whole semester, which can help to arrange classes in an optimal way. While studies show that more time spent on learning is positively correlated to schooling outcomes, the effect is moderate (Hattie, 2009; Kyriakides et al., 2010; Panayiotou et al., 2016).

When it comes to teaching quality, e-gradebooks contribute to a reduction of the time spent on non-teaching duties by allowing for automation of data 


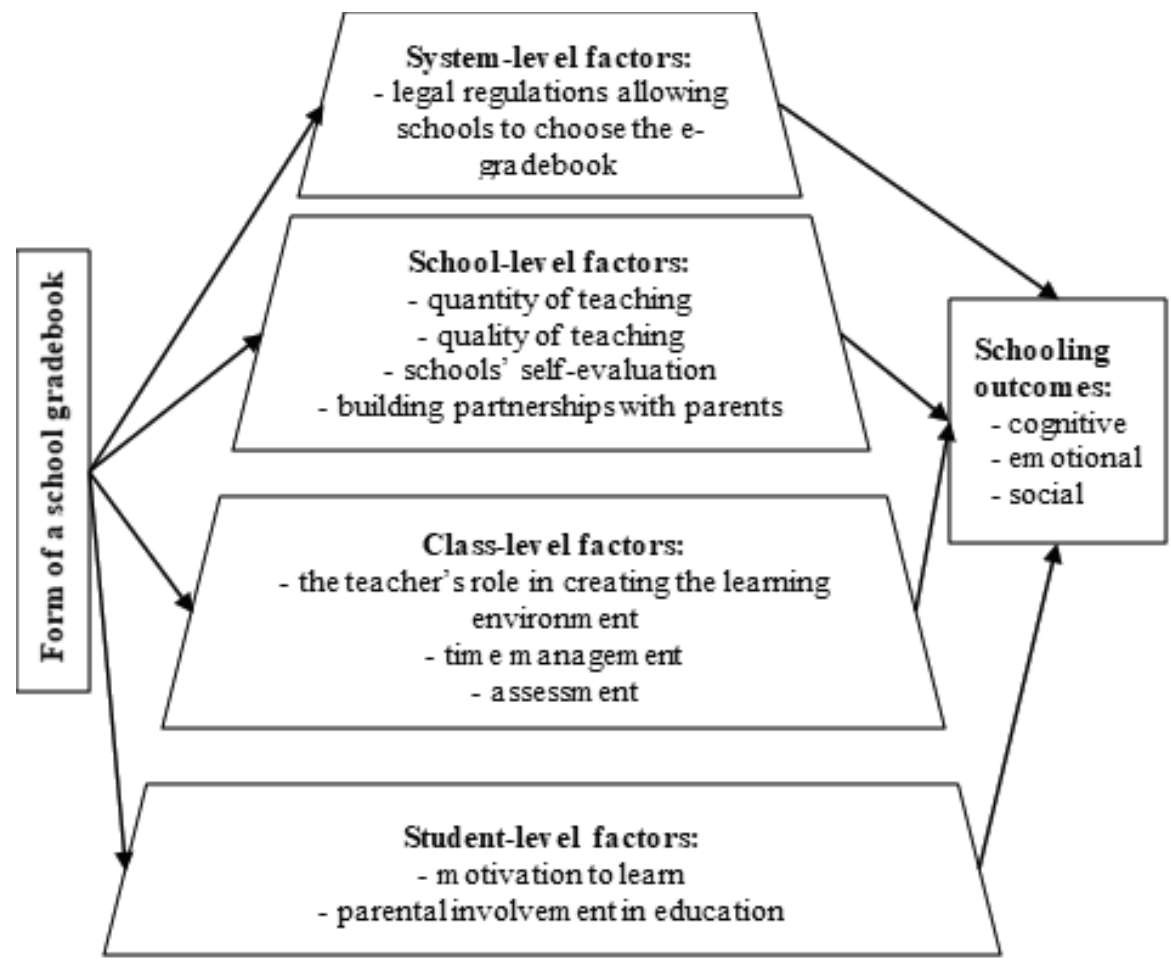

Figure 1. Structure of a dynamic model of school effectiveness, including those factors that can be linked to the way the school records are kept.

Source: Author's compilation.

preparation, faster information processing, and easier analysis of student results or planning of the class topics (Tomaszewska, 2014; Żebrok \& Smyrnova-Trybulska, 2015; Majewska, 2016). Thus, they release more time for higher quality teaching and the development of teaching skills.

The school policy on the quality of teaching is closely related to the factors at the class level: the teacher's role in creating the learning environment, time management and assessment (Creemers \& Kyriakidēs, 2008). The first concerns establishing the principles that create a learning environment and ensuring that they are respected. The e-gradebook can be a more effective tool than paper documentation in supporting discipline in the classroom, as information about students' behaviour is communicated faster and more directly to the parents (Dries, 2014; Majewska, 2016). The teacher's ability to manage time in a 
way that helps students remain focused and involved in the class tasks is an important predictor of learning outcomes (Wilks, 1996). The e-gradebook can also help use lesson time effectively by supporting teachers in their non-teaching duties, which makes space for better lesson planning and preparation.

With reference to assessment, e-gradebooks can increase the frequency and regularity of grading because they make it easier for heads to control the work of teachers in this area. They help shorten the time between the student's completion of an assignment and its assessment, as students usually have access to it as soon as it is entered online. Studies show that the time to give feedback is important for effective assessment (Bangert-Drowns et al., 1991; Hattie, 2009).

The gradebook is a place where the results of summative assessment are documented first of all (especially in a form of school grades). Teachers, however, also use other forms of grading, such as a commentary (written or oral) on a completed work or task. In addition, research shows that ongoing feedback, especially in the form of formative assessment, is much more positive for student achievement than school grades (Hattie \& Timperle, 2007; Brookhart, 2009). There is a risk that the electronic form of the gradebook, which supports summative rather than formative assessment, will marginalize the feedback associated with a constructivist approach to assessment. This could result in lower learning outcomes. Transferring grading to an online tool may also reduce real-world interaction between teachers and students during the grading process. More research is certainly needed into whether and how moving to an electronic gradebook changes the practice of ongoing grading.

E-gradebooks have certainly reduced the time it takes for parents to receive feedback on their children's grades, so they may feel like equal partners in information processing. But as expressed by a child in lower secondary education, there are some risks: "Unfortunately it is sometimes the case that she [my mum] knows sooner than I do what grade my teacher gave me for the test or homework" (Kałużna, 2014), so students may no longer treat assessments as feedback given to support their learning and, as a result, may stop engaging in the learning process (Deci et al., 1999). In addition, if a child's grades do not meet parents' expectations, students may look for strategies to get more satisfying grades without increasing their achievement level (Hattie \& Timperle, 2007).

Building partnerships with the local environment, in this case with parents, is another school-level factor of effectiveness (Creemers \& Kyriakidēs, 2008). Thanks to the already mentioned faster and more direct way of providing parents with information and easier communication between school and home, e-gradebooks can affect the level of parents' engagement in their child's education. 
The belief in the positive effect of parental involvement seems so widespread that it might seem unquestionable. Yet although the overall effect of parental involvement is positive (Jeynes, 2005; Hattie, 2009), its different forms are to varying degrees linked to school achievement. Parents' educational aspirations are most relevant to children's achievement (Hong \& Ho, 2005; Hattie, 2009; Boonk et al., 2018) while some forms of parental supervision (e.g. monitoring homework, over-controlling the way a child spends his or her time, or frequent disciplinary measures) are less positively or even negatively related to learning outcomes (Fan \& Chen, 2001; Hong \& Ho, 2005; Hattie, 2009; Boonk et al., 2018).

Research by Maja Deković and Wim Meeus (1997) shows a negative correlation between parents' supervision of the child's leisure time and children's engagement with peers. Others have demonstrated that parents' controlling behaviour, demanding obedience, resorting to punishment and the consequent power imbalance, can result in children experiencing difficulties in social relationships, lower self-esteem and anxiety of comparing themselves to others (Cripps \& Zyromski, 2009). A study by Sandra Moroni et al. (2015) showed that if children perceived parents' involvement in homework as supportive, it was positively related to their performance, while if parents' actions were perceived as intrusive and controlling, it had the opposite effect. Furthermore, research suggests that parental supervision is negatively linked to children's internal locus of control (Hong \& Ho, 2005). In contrast, external locus of control is correlated with a lower level of academic self-concept and, in the case of girls, a poorer assessment of their social and other, more general, skills (Lau \& Leung, 1992) and thus lower achievement (Findley \& Cooper, 1983).

At present, no data is available in Poland that could show whether and how the shift in the form of school record-keeping from paper to electronic actually contributes to changes in parental involvement in children's education. The little data there is show that a vast majority of Polish parents regularly check e-gradebook information about their child (mainly grades and attendance), and that a third do so daily (Tomaszewska, 2014). The few studies conducted in the United States demonstrate that online access to student records influenced parents' use of rewards and discipline at home (Dries, 2014).

It is also worth noting that the dynamic model of educational effectiveness focuses on the processes and activities that are undertaken in schools to improve teaching and learning environments. The overriding effectiveness factor at the school level is internal evaluation of activities (Panayiotou et al., 2016). The electronic gradebook can be a valuable tool supporting heads and teachers in this process thanks to the facilitated analysis of data collected in electronic form 
and the modules for automatic creation of selected data sets (Wróbel, 2009; Tomaszewska, 2014; Majewska, 2016).

\section{The current study}

The analysis presented here aims to answer the question of whether the form of school record-keeping is relevant to schooling outcomes in primary schools. It brings us closer to understanding the effects of changing the form of gradebook to electronic, providing the missing empirical evidence for the process of rationalizing the discussion about e-gradebooks.

The dynamic model of educational effectiveness assumes that schooling outcomes should be considered in a broader context than achievements measured by standardized tests (Creemers \& Kyriakidēs, 2008, p. 75); however, so far studies have rarely gone beyond the measurement of competences in the main school subjects. This may result in our failure to see a full picture of the consequences of actions taken by schools. Therefore, in the present study, in addition to measuring school achievement, the available measures of social and emotional outcomes which, as shown above, may be indirectly linked to the form of the gradebook have been also used.

Answers were sought to the following research questions: whether primary schools using e-gradebooks differed from schools using paper gradebooks in terms of: (1) teaching effectiveness in key school achievements and (2) educational outcomes related to emotional integration with the school, perceived quality of peer relations and academic self-concept.

The available data is not sufficient for us to take into account directly in the analyses the efficiency factors listed in Figure 1, but only for an examination of the relationships between the form of gradebook and schooling outcomes. However, the theoretical introduction that considers the selected effectiveness factors at four levels showed that such a relationship could be expected.

\section{Method}

\section{Data}

This article has been prepared using data from the longitudinal study "School Determinants of Teaching Effectiveness Study" (SUEK ${ }^{1}$ ) carried out on a random,

1 The research was a part of the project Quality and Effectiveness of Education and Strengthening of Institutional Research Capabilities, co-financed by the European Union under the European Social Fund, and implemented by the Educational Research Institute. 
nationwide, representative sample of primary school students (Dolata, 2014). In this study the sample consisted of 4,500 students from 171 primary schools.

\section{Procedure}

The SUEK study was carried out in 7 stages (between 2010 and 2015); data were drawn from 3 of them. In grade 3, (turn of 2010 and 2011) intelligence, the three dimensions of school integration and the socio-economic status of the student's family were measured. At the beginning of grade 4 , students took achievement tests. At the end of grade 6, (04-05.2014) school achievements and levels of school integration were re-measured and the information about the form of gradebook used in the school was gathered. The data was collected by means of paper questionnaires and tests completed by the respondents.

\section{Measurements}

\section{Form of a gradebook}

The data was obtained from school heads. The electronic gradebook was used in $32 \%$ of schools (in $40 \%$ in towns with over 5,000 inhabitants and in $25 \%$ in small towns and villages).

\section{Educational outcomes}

School achievement was examined in three areas - reading, writing and math - by using TOS3 and TOS6 standardized achievement tests, which were developed specifically for the SUEK study on the basis of a consistent concept (Jasińska \& Modzelewski, 2014; Modzelewski, 2015). The results of the measurement were scaled for each skill area separately using a one-dimensional Rasch model. Expected a Posteriori (EAP) estimates were used as an indicator of school achievement; the results were presented on a scale with a mean of 100 and standard deviation of 15 .

Social and emotional outcomes. The study took advantage of the Perceptions of Inclusion Questionnaire in the Polish adaptation prepared by Grzegorz Szumski (2010), which allows us to measure emotional integration, social integration and academic self-concept (15 statements per scale). The confirmatory factor analyses calculated on polychoric correlation matrices using WLSMV estimator confirmed a sufficiently good fit to the data of the three-dimensional model (grade 3: $\mathrm{RMSEA}=0.043 ; \mathrm{TLI}=0.831 ; \mathrm{CFI}=0.839$; grade 6 : $\mathrm{RMSEA}$ $=0.062 ; \mathrm{TLI}=0.895 ; \mathrm{CFI}=0.900)$. The emotional integration scale measures how well a student feels at school emotionally (e.g. "I feel no desire to go to school", reverse coding of responses). The social integration scale measures the 
quality and quantity of peer relationships in the class and at school (e.g. "I get along very well with my classmates"). The academic self-concept scale shows how students see themselves and their competences in the school context (e.g. "Many things at school are too difficult for me"; reverse coding of responses). The factor scores were used as indicators across the three dimensions of integration, which have been presented on a scale with a mean of 100 and a standard deviation of 15 .

\section{Controlled variables}

Intelligence. Raven's Progressive Matrices test, standard version, classic form was used (TMS-K). The results of the measurement were scaled using a one-dimensional two-parameter IRT model. Expected a Posteriori (EAP) estimates were used as an indicator of fluid intelligence; the results were presented on a scale with a mean of 0 and standard deviation of 1 .

$A C H 3$. The total achievement indicator after grade 3 was calculated as the estimation of the first factor value from the analysis of the main components in the results of the three achievement tests described above (it explained $82.26 \%$ of the total variance of the variables).

\section{Sex. Information provided in the questionnaire.}

Older than the main cohort. It assumes the value of 1 when the respondent's year of birth is earlier than the dominant year of birth of children in the class.

Socio-economic status of the family. The levels of parents' education were assigned scale values in the years of study needed to achieve a given level of education (e.g. primary - 8; higher MA - 17). The indicator was calculated as the highest value available (called $H E D U$ ). The level of material resources at the family's disposal (home resources) was built on the basis of three questions: the number of books in the home, the number of children's books, and the provision of material goods which are educational in nature (e.g. dictionaries). The indicator was created by using IRT scaling (2PL/GRM model) (Dolata, 2014).

Size of the town/village. The index takes the value of 1 when the school is in a town with more than 5000 and 0 in other cases.

\section{Data analysis methods}

Hierarchical linear regression models with a random effect (Snijders \& Bosker, 2012) were used, which corresponded to the multilevel character of the dynamic model of educational effectiveness. 
For each of the six dependent variables analyzed (three achievement areas and three integration dimensions), the optimum model with control variables was established in the initial steps. The article presents models with the control variables which proved to be important predictors of the dependent variable. In the last step, a variable was included in the models indicating whether the school uses an electronic gradebook. The analyses were performed with the maximum likelihood method, using Stata 14.2 software. Non-standardized coefficients are presented in the tables.

In order to estimate the percentage of explained variance, the pseudo $\mathrm{R}^{2}$ coefficient was used (Domański \& Pokropek, 2011). The variance of school effects and the variance at the student level show the part of the variance of the dependent variable that could not be explained by the independent variables included in the model.

As a control variable, all models included the results of a measurement of the same characteristic to which the dependent variable relates but carried out three years earlier. Therefore, they allow us to examine the significance of the use of e-gradebooks by schools for relative gains in achievement or student integration. These models of analysis are commonly used in studies of educational effectiveness (Snijders \& Bosker, 2012).

\section{Results}

The effect of the e-gradebook for school achievement was close to zero and statistically insignificant in the models in which the previous achievements, intelligence level, gender and socio-economic status of the student's family were controlled (see Table 1). Similar conclusions were reached by models that additionally controlled for the size of the village/town/city where the school was located (variable not included in the final model due to the lack of statistical significance).

However, a statistically significant, although not very sizeable, effect of the e-gradebook was found when it came to the relative change in students' academic self-concept. In schools where e-gradebooks were used, students assessed their learning competences as being a little worse than students from schools that kept paper gradebooks. This correlation was observed under control of the level of school self-concept three years earlier, of the level of intelligence, school performance and the socio-economic status of the family. This effect is significant at the level of $p<0.05$, but a small sample size (171) and a small inter-school variance of academic self-concept $(1.3 \%$ of variance of the variable is the inter-school variance) justify the adoption of a less restrictive statistical significance level. 
Table 1. The relationship between the schools' use of an e-gradebook and results of school achievement tests

\begin{tabular}{|c|c|c|c|c|c|c|}
\hline \multirow[t]{2}{*}{ Dependent variable } & \multicolumn{2}{|c|}{ reading } & \multicolumn{2}{|c|}{ writing } & \multicolumn{2}{|c|}{ math } \\
\hline & b & (s.e.) & $\mathrm{b}$ & (s.e.) & $\mathrm{b}$ & (s.e.) \\
\hline \multicolumn{7}{|l|}{ Fixed effects estimates } \\
\hline \multicolumn{7}{|l|}{ Student level } \\
\hline Intelligence & $2.87^{\star \star *}$ & $(0.22)$ & $2.12^{\star \star \star}$ & $(0.20)$ & $2.56^{* * *}$ & $(0.22)$ \\
\hline TOS31 & $0.49^{* \star *}$ & $(0.01)$ & $0.56^{* \star *}$ & $(0.02)$ & $0.59^{\star \star *}$ & $(0.02)$ \\
\hline $\operatorname{Sex}(F)$ & $4.99^{\star \star *}$ & $(0.36)$ & $6.07^{* \star *}$ & $(0.30)$ & & \\
\hline $\begin{array}{l}\text { Older than the main } \\
\text { cohort }\end{array}$ & & & $-4.09^{* *}$ & $(1.24)$ & & \\
\hline HEDU & $0.34^{* * *}$ & $(0.08)$ & $0.52^{* * *}$ & $(0.06)$ & $0.61^{* * *}$ & $(0.06)$ \\
\hline Home resources & $1.36^{\star *}$ & $(0.44)$ & $1.13^{*}$ & $(0.46)$ & $0.92^{*}$ & $(0.45)$ \\
\hline Intercept & $45.58^{\star \star *}$ & $(1.64)$ & $33.52^{* * *}$ & $(1.59)$ & $33.02^{* * *}$ & $(1.69)$ \\
\hline \multicolumn{7}{|l|}{ School level } \\
\hline E-gradebook & -0.03 & $(0.74)$ & 0.03 & $(0.74)$ & -0.47 & $(0.70)$ \\
\hline \multicolumn{7}{|l|}{ Random effects estimates } \\
\hline $\begin{array}{l}\text { Variance of school } \\
\text { effects }\end{array}$ & 15.41 & $(2.53)$ & 17.05 & (3.19) & 15.02 & $(1.89)$ \\
\hline $\begin{array}{l}\text { Variance at the stu- } \\
\text { dent level }\end{array}$ & 105.06 & $(2.57)$ & 79.62 & $(2.38)$ & 82.07 & (2.26) \\
\hline \multicolumn{7}{|l|}{ Summary } \\
\hline Number of schools & 171 & & 171 & & 171 & \\
\hline Number of students & 4412 & & 4420 & & 4360 & \\
\hline Pseudo R2 & 0.469 & & 0.577 & & 0.572 & \\
\hline
\end{tabular}

${ }^{1}$ TOS3 - the models have considered, as appropriate, for the subsequent dependent variables, the results of tests after grade 3 in reading, writing and math

${ }^{*} p<0.05 ;{ }^{* *} p<0.01 ;{ }^{* *} p<0.001$

Source: Author's research.

Table 2 presents the relationship between the use of e-gradebooks and other educational outcomes. The relative change in the level of student emotional and social integration was not significantly related to the form of the gradebook. 
Table 2. The relationship between the schools' use of an e-gradebook and student integration

\begin{tabular}{|c|c|c|c|c|c|c|}
\hline \multirow[t]{2}{*}{ Dependent variable } & \multicolumn{2}{|c|}{ emotional integration } & \multicolumn{2}{|c|}{ social integration } & \multicolumn{2}{|c|}{ academic self-concept } \\
\hline & $\mathrm{b}$ & (s.e.) & $b$ & (s.e.) & $\mathrm{b}$ & (s.e.) \\
\hline \multicolumn{7}{|l|}{ Fixed effects estimates } \\
\hline \multicolumn{7}{|l|}{ Student level } \\
\hline KIU3' & $0.32^{\star * \star}$ & $(0.01)$ & $0.32^{\star * *}$ & $(0.02)$ & $0.36^{\star \star *}$ & $(0.02)$ \\
\hline $\operatorname{Sex}(F)$ & $4.67^{* * *}$ & $(0.49)$ & & & & \\
\hline $\mathrm{ACH}^{2}$ & & & & & $0.26^{* * *}$ & $(0.02)$ \\
\hline Intelligence & & & & & $0.90^{\star \star}$ & $(0.27)$ \\
\hline Older than the main cohort & & & $-6.74^{\star \star *}$ & $(1,90)$ & & \\
\hline HEDU & & & & & $0.46^{* * *}$ & $(0.09)$ \\
\hline Home resources & $2.18^{\star *}$ & $(0.64)$ & & & $2.91^{* * *}$ & $(0.61)$ \\
\hline Intercept & $66.95^{\star * *}$ & $(1.52)$ & $69.35^{\star \star \star}$ & $(1.90)$ & $85.14^{\star \star *}$ & $(3.20)$ \\
\hline \multicolumn{7}{|l|}{ School level } \\
\hline Town over 5000 & $-1.52^{*}$ & $(0.72)$ & $-2.18^{* * *}$ & $(0.62)$ & $-1.79^{\star \star *}$ & $(0.47)$ \\
\hline Electronic gradebook & -0.24 & $(0.70)$ & -0.4 & $(0.64)$ & $-1.17^{*}$ & $(0.50)$ \\
\hline \multicolumn{7}{|l|}{ Random effects estimates } \\
\hline Variance of school effects & 12.37 & $(2.00)$ & 7.97 & $(2.52)$ & 2.63 & $(1.11)$ \\
\hline Variance at the school level & 176.35 & $(4.10)$ & 188.97 & $(4.71)$ & 146.21 & $(4.59)$ \\
\hline \multicolumn{7}{|l|}{ Summary } \\
\hline Number of schools & 171 & & 171 & & 171 & \\
\hline Number of students & 4535 & & 4527 & & 4317 & \\
\hline Pseudo $\mathrm{R}^{2}$ & 0.163 & & 0.126 & & 0.338 & \\
\hline
\end{tabular}

${ }^{1} \mathrm{KIU} 3$ - the models have considered, for subsequent dependent variables, the corresponding results of measurement in grade 3 for the school integration scale, peer integration and self-concept

$\mathrm{ACH} 3$ - total achievement indicator at the end of grade 3

${ }^{*} p<0.05 ;{ }^{* *} p<0.01 ;{ }^{* * *} p<0.001$

Source: Author's research.

\section{Discussion}

The study shows that the use of e-gradebooks is not linked to teaching effectiveness in reading, writing or math. Students of schools that use e-gradebooks obtain results comparable to those in schools that keep paper records when the previous performance, student intelligence and socio-economic status of their families is controlled for in the models. 
Our results do not confirm the opinions of e-gradebook users presented in the introduction. Neither do they confirm the results of studies by American researchers who observed a positive relationship between the frequency of parents' use of the e-gradebook and students' achievements, though these studies did not control for the status of students' families or their previous achievements (Brown, 2014; Dries, 2014).

However, our analysis does not include information on the ways e-gradebooks are used by teachers, headmasters and parents (e.g. the number functions employed and the level of intensity of its use or whether teachers actually use the time saved for a better preparation of classes and use the function of creating data statements to self-evaluate their own work). These aspects might be crucial for the effectiveness of the electronic form of record-keeping (Creemers \& Kyriakidēs, 2008, p. 84).

The lack of relationship between the form of gradebook and school effectiveness may also be explained in terms of the balancing of positive and negative influences of the e-gradebook. It can become a tool for parents to control their children's learning process and as noted here, some studies show that excessive parental control is negatively correlated with school achievement (Karbach et al., 2013; Su et al., 2015). Polish research (Szumski \& Karwowski, 2015) has also demonstrated a negative relationship between achievements and the parental style of motivating children which has become more readily available due to e-gradebook use, i.e. focus on school grades and comparing their child with others.

Our study shows that out of the three educational outcomes measured (emotional integration, social integration and academic self-concept), the use of an e-gradebook was associated with only one. It was found to be not very strongly negative in relation to academic self-concept (with the previous level of academic self-concept, level of achievement, intelligence and socio-economic status of the family being controlled). This means that if we compare schools that do not statistically differ in terms of these student characteristics, in schools that use e-gradebooks, children make worse assessments of their school competences than students from schools with paper gradebooks. The results of research on mediators of the relationship between parental involvement and school achievement show that high parental academic pressure is negatively linked to self-concept (Rogers et al., 2009) and self-efficacy (Puklek Levpušček $\&$ Zupančič, 2009). So perhaps e-gradebooks intensify the controlling behaviour of parents, which would explain the observed relationship. 
The study by Jolanta Pisarek and Paweł Grygiel (2015) demonstrated the high significance of grades for students' self-concept. Notably, by using e-gradebooks parents have much easier access to information about grades and may therefore focus on them, making grades also more relevant to students. If parents are more likely to respond to low rather than high grades, this could also explain the link between the use of e-gradebooks and lower self-concept.

These results show how important it is to investigate whether switching to electronic gradebook contributes to changes in parental involvement in schooling, and whether parents give in to the temptation of excessive control, which can cause a decline in students' self-concept and contribute to lower school achievement (Rogers et al., 2009; Karbach et al., 2013).

Regardless of the limitations of this study, its results concerning the lack of connection between the form of the gradebook and school effectiveness are of considerable practical relevance. They not only contribute to the rationalization of the discussion about e-gradebooks, but also show that it cannot be expected that switching to electronic gradebook readily translates into improved learning outcomes.

The study also shows that the effects of the changes introduced in schools may have much more complex impact than previously discussed, and should be therefore analyzed in a broader context. Further research is needed on a possible link between the gradebook form and changes in parental behaviour and attitudes, and whether the opportunities offered by e-gradebooks can be used to provide real support for students and teachers throughout the teaching and learning process.

\section{Conclusions and policy implications}

Our results have not confirmed the commonly shared belief that the use of egradebook increases teaching effectiveness. What they have shown is the need to rationalize our discussion on the role of modern technologies in the teaching process, and more than anything to base more arguments on the actual research. The mere introduction of modern technologies into education does not have to necessarily translate directly into better learning outcomes. We should focus on ways of using modern technologies that make them really supportive in teaching and learning, considering the actual needs of teachers and students related to the effective implementation of these solutions.

The results of the presented study in no way negate the relevance of new technologies in the educational process. In fact, the article discusses an important but narrowly defined problem. The importance of the e-gradebook for the 
educational process is undoubtedly worth thinking about in more detail, as the recent experience related to the COVID-19 pandemic has clearly shown. In a situation where it is necessary to switch to remote learning, the e-gradebook is often the only commonly available tool for communication and remote assessment used in Poland (Librus, 2020; Pyżalski, 2020). An interesting direction of further research would be the investigation of the role of e-gradebooks in the process of distant learning.

The negative relationship between the use of e-gradebooks at school and students' self-assessment, as found in the study, has shown that some changes introduced in education may have more complex effects than are commonly accepted. When the form of the gradebook is changed to electronic, psychological factors come to the fore, such as students' school self-assessment and its link to parents' involvement on the basis of their immediate access to the e-gradebook. The results have also shown that the evaluation of the outcomes of the changes introduced should not be limited to the perspective of school performance. The social and emotional effects should not disappear from the focus of not only researchers, but also representatives of the education system.

\section{References}

Brown, L. D. (2014). The Impact of the Usage of Electronic Grade Books on Student Achievement and Parental Satisfaction. Walden University.

Bangert-Drowns, R. L., Kulik, C.-L. C., Kulik, J. A., \& Morgan, M. (1991). The Instructional Effect of Feedback in Test-Like Events. Review of Educational Research, 61(2), 26, doi: $10.3102 / 00346543061002213$.

Boonk, L., Gijselaers, H. J. M., Ritzen, H., \& Brand-Gruwel, S. (2018). A Review of the Relationship Between Parental Involvement Indicators and Academic Achievement. Educational Research Review, 24, 10-30, doi: 10.1016/j.edurev.2018.02.001.

Brookhart, S. M. (2009). Assessment and Examinations. In: L. J. Saha, \& A. G. Dworkin (Eds.), International Handbook of Research on Teachers and Teaching (pp. 723-738). Springer Science+Business Media.

Bryska, M. (2014). Rodzice są partnerami szkoły [Parents as School Partners]. In: G. Mazurkiewicz, \& A. Gocłowska (Eds.), Jakość edukacji. Dane i wnioski z ewaluacji zewnętrznych prowadzonych w latach 2012-2013 [The Quality of Education. Data and Conclusions from External Evaluations Conducted in the Years 2012-2013], (pp. 153-174). Wydawnictwo Uniwersytetu Jagiellońskiego. 
Creemers, B. P. M., \& Kyriakidēs, L. (2008). The Dynamics of Educational Effectiveness: A Contribution to Policy, Practice and Theory in Contemporary Schools. UK: Routledge.

Cripps, K., \& Zyromski, B. (2009). Adolescents' Psychological Well-Being and Perceived Parental Involvement: Implications for Parental Involvement in Middle Schools. RMLE Online, 33(4), 1-13, doi: 10.1080/19404476.2009.11462067.

Deci, E. L., Koestner, R., \& Ryan, R. M. (1999). A Meta-Analytic Review of Experiments Examining the Effects of Extrinsic Rewards on Intrinsic Motivation. Psychological Bulletin, 125(6), 627-668, doi: 10.1037/0033-2909.125.6.627.

Deković, M., \& Meeus, W. (1997). Peer Relations in Adolescence: Effects of Parenting and Adolescents' Self-concept. Journal of Adolescence, 20(2), 163-176, doi: 10.1006/ jado.1996.0074.

Dolata, R. (Ed.). (2014). Czy szkoła ma znaczenie? Analiza zróżnicowania efektywności nauczania na pierwszym etapie edukacyjnym [Does School Matter? Analysis of Teaching Effectiveness at the First Stage of Primary Education (1-3 Grades)]. Warszawa: Instytut Badań Edukacyjnych.

Domański, H., \& Pokropek, A. (2011). Podziały terytorialne, globalizacja a nierówności spoteczne: Wprowadzenie do modeli wielopoziomowych [Territorial Divisions, Globalization and Social Inequalities: An Introduction to Multilevel Models]. Warszawa: Wydawnictwo IFiS PAN.

Dries, S. D. (2014). The Influence of Parent Portal Access on Student Efficacy and Parental Involvement. Seton Hall University.

Dżus, E. (2010). Polecam e-dziennik wszystkim szkołom [I Recommend the E-gradebook to All Schools; Interview]. Retrived 20 March 2020 from http://szczecin.wyborcza.pl/szc zecin/1,34939,7935329,Polecam_e_dziennik_wszystkim_szkolom.html.

Fan, X., \& Chen, M. (2001). Parental Involvement and Students' Academic Achievement: A Meta-Analysis. Educational Psychology Review, 13(1), 1-22, doi: 10.1023/ A:1009048817385.

Findley, M. J., \& Cooper, H. M. (1983). Locus of Control and Academic Achievement: A literature Review. Journal of Personality and Social Psychology, 44(2), 419-427, doi: 10.1037/0022-3514.44.2.419.

Hattie, J. (2009). Visible Learning: A Synthesis of Over 800 Meta-Analyses Relating to Achievement. Routledge.

Hattie, J., \& Timperle, H. (2007). The Power of Feedback. Review of Educational Research, 77(1), 81-112, doi: 10.3102/003465430298487. 
Hong, S., \& Ho, H.-Z. (2005). Direct and Indirect Longitudinal Effects of Parental Involvement on Student Achievement: Second-Order Latent Growth Modeling Across Ethnic Groups. Journal of Educational Psychology, 97(1), 32-42, doi: 10.1037/00220663.97.1.32.

Isio-Kurpińska, K. (2017, May 12). Dziennik elektroniczny a relacje z dzieckiem [Electronic Gradebook and Relations with the Child]. Retrived 20 March 2020 from https://edurada.pl/artykuly/dziennik-elektroniczny-a-relacje-z-dzieckiem/

Jasińska, A., \& Modzelewski, M. (2014). Testy osiągnięć szkolnych TOS3: Przykład narzędzia skonstruowanego z wykorzystaniem modelu Rascha [TOS3 School Achievement Tests - A Set of Three Tests Developed Using the Rasch Measurement Model]. Edukacja, 2(127), 85-107.

Jeynes, W. H. (2005). A Meta-Analysis of the Relation of Parental Involvement to Urban Elementary School Student Academic Achievement. Urban Education, 40(3), 237-269, doi: $10.1177 / 0042085905274540$.

Kałużna, P. (2014). E-dzienniki nie podobają się tylko uczniom. Nie mogą już 'ściemniać' rodzicom [Students Do Not Like E-gradebook. They Can Not Cheat Parents Anymore]. Przegląd Koniński, 1.

Karbach, J., Gottschling, J., Spengler, M., Hegewald, K., \& Spinath, F. M. (2013). Parental Involvement and General Cognitive Ability as Predictors of Domain-Specific Academic Achievement in Early Adolescence. Learning and Instruction, 23, 43-51, doi: 10.1016/j.learninstruc.2012.09.004.

Kempka, M. (2014). List otwarty na temat e-dzienników [An Open Letter on E-gradebook]. Edunews.Pl. Retrived 10 March 2020 from https:/www.edunews.pl/badania-i-debaty/ dyskusje/2771-list-otwarty-na-temat-e-dziennikow.

Kyriakides, L., Creemers, B., Antoniou, P., \& Demetriou, D. (2010). A Synthesis of Studies Searching for School Factors: Implications for Theory and Research. British Educational Research Journal, 36(5), 807-830, doi: 10.1080/01411920903165603.

Lau, S., \& Leung, K. (1992). Self-Concept, Delinquency, Relations with Parents and School and Chinese Adolescents' Perception of Personal Control. Personality and Individual Differences, 13(5), 615-622, doi: 10.1016/0191-8869(92)90203-2.

Librus (2020). Nauczanie zdalne. Jak wyglada w naszych domach. Raport z badania Ankietowego [Distance Learning. What Does it Look Like in Our Homes? A Survey Report]. Retrived 10 March 2020 from https://portal.librus.pl/artykuly/nauczanie-zdalne-jakwyglada-w-naszych-domach-pobierz-raport.

Majewska, K. (2016). Electronic Class Register in the Process of Teaching and Upbringing. In: D. Siemieniecka (Ed.), New Technologies in Education and Communication (pp. 127-137). Toruń: Wydawnictwo Naukowe Uniwersytetu Mikołaja Kopernika. 
MEN [Ministry of National Education] (2009). Rozporządzenie Ministra Edukacji Narodowej z dnia 16 lipca 2009 r. zmieniające rozporządzenie w sprawie sposobu prowadzenia przez publiczne przedszkola, szkoły i placówki dokumentacji przebiegu nauczania, działalności oświatowej i opiekuńczej oraz rodzajów tej dokumentacji (Dz.U. $2009 \mathrm{Nr} 116$ poz. 977) [ The Decree by the Minister of National Education of July 162009 , amending the Regulation on the way public pre-schools, schools and institutions keep documentation of the course of teaching, educational and care activities and types of such documentation (OJ 2009, no 116, item 977)].

Modzelewski, M. (2015). Co umieją szóstoklasiści i jak to zmierzono? [What Do Sixth Grade Students Know and How Was It Measured?]. In: Szkolne pytania. Wyniki badań nad efektywnościa nauczania w klasach IV-VI [Questions about School. Research Results on the school effectiveness in grades 4-6]. Warszawa: Instytut Badań Edukacyjnych.

Moroni, S., Dumont, H., Trautwein, U., Niggli, A., \& Baeriswyl, F. (2015). The Need to Distinguish Between Quantity and Quality in Research on Parental Involvement: The Example of Parental Help with Homework. The Journal of Educational Research, 108(5), 417-431, doi: 10.1080/00220671.2014.901283.

Panayiotou, A., Kyriakides, L., \& Creemers, B. P. M. (2016). Testing the Validity of the Dynamic Model at School Level: A European study. School Leadership \& Management, 36(1), 1-20, doi: 10.1080/13632434.2015.1107537.

Pisarek, J., \& Grygiel, P. (2015). Czy warto dbać o samoocenę szkolną uczniów? [Is It Worth Taking Care of Students' Academic Self-Concept?]. In: R. Dolata, P. Grygiel, D. Jankowska, A. Jasińska-Maciążek, M. Karwowski, M. Modzelewski, \& J. Pisarek (Eds.), Szkolne pytania. Wyniki badań nad efektywnościa nauczania w klasach IV-VI [Questions about School. Research Results on the School Effectiveness in Grades 4-6], (pp. 72-84). Warszawa: Instytut Badań Edukacyjnych.

Puklek Levpušček, M., \& Zupančič, M. (2009). Math Achievement in Early Adolescence: The Role of Parental Involvement, Teachers' Behavior, and Students' Motivational Beliefs About Math. The Journal of Early Adolescence, 29(4), 541-570, doi: $10.1177 / 0272431608324189$.

Pyżalski, J. (Ed.) (2020). Edukacja w czasach pandemii wirusa COVID-19. Z dystansem o tym, co robimy obecnie jako nauczyciele [Education During the COVID-19 Pandemic. With the Distance about What We Are Currently Doing as Teachers]. Warszawa: EduAkcja.

Rogers, M. A., Theule, J., Ryan, B. A., Adams, G. R., \& Keating, L. (2009). Parental Involvement and Children's School Achievement: Evidence for Mediating Processes. Canadian Journal of School Psychology, 24(1), 34-57, doi: 10.1177/0829573508328445.

Scheerens, J. (2013). The Use of Theory in School Effectiveness Research Revisited. School Effectiveness and School Improvement, 24(1), 1-38, doi: 10.1080/09243453.2012.691100. 
Snijders, T. A. B., \& Bosker, R. J. (2012). Multilevel Analysis: An Introduction to Basic and Advanced Multilevel Modeling, 2th ed. UK: Sage.

Stasik, R. (2015). Dziennik elektroniczny - Przyszłość nowoczesnej szkoły? [Electronic Gradebook - The Future of a Modern School?] Miasto z Wizją. Retrived 5 March 2020 from https://miastozwizja.pl/dziennik-elektroniczny-przyszlosc-nowoczesnej-szkoly.

Su, Y., Doerr, H. S., Johnson, W., Shi, J., \& Spinath, F. M. (2015). The Role of Parental Control in Predicting School Achievement Independent of Intelligence. Learning and Individual Differences, 37, 203-209, doi: 10.1016/j.lindif.2014.11.023.

Szumski, G. (2010). Wokót edukacji włączającej: Efekty ksztatcenia uczniów z niepetnosprawnościa intelektualna $w$ stopniu lekkim $w$ klasach specjalnych, integracyjnych i ogólnodostęnych [Inclusive Education: Learning Outcomes of Students with Mild Intellectual Disabilities in Special, Integration and Public Classes I]. Warszawa: Wydawnictwo Akademii Pedagogiki Specjalnej.

Szumski, G., \& Karwowski, M. (2015). Rodzicielskie zaangażowanie w naukę gimnazjalistów sprawnych i ze specjalnymi potrzebami edukacyjnymi [Parents' Engagement into Education of Lower Secondary School Students with and without the Special Educational Needs - which Stategies Bring Expected Results?]. Edukacja, 135(4), 17.

Tomaszewska, A. (2014). E-dziennik jako element kultury informacyjnej szkoły [E-register as a Part of School's Information Culture]. Edukacja Humanistyczna, 31(2), 197-208.

Tuczyński, K. (2015). Techniczno-informatyczne kierunki rozwoju systemów elektronicznego zarządzania szkołą [IT Trends in the Development of Electronic School Management Systems]. Kwartalnik Edukacyjny, 83(4), 58-68.

Vulcan. (n.d.). Jakie byty cele dyrektora we wdrożeniu e-dziennika? Jakie problemy rozwiazat? [What Were the School Director's Goals in Implementing the E-gradebook? What Problems Did It Solve?]. Retrived 20 March 2020 from https://www.vulcan.edu. pl/vulcang_files/user/Referencje/VULCAN-referencje-dyrektorzy.pdf.

Wilks, R. (1996). Classroom Management in Primary Schools: A Review of the Literature. Behaviour Change, 13(1), 20-32, doi: 10.1017/S0813483900003922.

Wróbel, M. (2009). E-dziennik jako narzędzie wspierające proces edukacji szkolnej [E-gradebook as a Tool Supporting the Process of School Education]. E-Mentor, 31(4). http:// www.e-mentor.edu.pl/artykul/index/numer/31/id/675.

Żebrok, P., \& Smyrnova-Trybulska, E. (2015). Electronic Registers at School and Determinants of their Effective Implementation. In: E. Smyrnova-Trybulska (Ed.), IT toolsGood practice of effective use in education: Monograph. Studio Noa; University of Silesia. Faculty of Ethnology and Sciences of Education. 
ORYGINALNE ARTYKUŁY BADAWCZE

Zielińska, M. (2017). Interpersonalne kontakty nauczycieli z rodzicami w dobie dziennika elektronicznego [Interpersonal Teacher - Parent Relations in the Age of Electronic School Diary]. Edukacja - Technika - Informatyka, 21(3), 157-162, doi: 10.15584/ eti.2017.3.22. 